\title{
Current Status of Dominant Pelagic Fish Species Caught by Purse Seine in the Eastern Sulu Sea and the Basilan Strait
}

\author{
Romeo De Guzman ${ }^{1}$, Regina May Calangit ${ }^{1, \star}$, Pedling Munap ${ }^{1}$, Jonalyn Alberto ${ }^{1}$, Maricris Orinza ${ }^{1}$ \\ ${ }^{1}$ Bureau of Fisheries and Aquatic Resources Regional Office No. IX, R.T Lim Kawa-Kawa, Zamboanga City \\ Regional Field Office 6, Iloilo City
}

\section{A B S T R A C T}

Data collection was conducted in four (4) pre-identified fish landing sites in Zamboanga City. Sampling was conducted every other two days of the month with the third day as a rest day. The strategies used included interviews with fishers and/or boat captains to determine fishing grounds, type of gear used, total catch, and the number of fishing days. Two data collectors per site determine the species, length (total length if small, and fork length on larger fish), and the weight measurements from the one kilo of samples extracted from the total catch. Results show that the CPUE for the whole commercial fisheries subsector averaged 10,890.5 kg/ day while the purse seine, which is the most prevalent gear employed, had a higher average CPUE of 14,142 $\mathrm{kg} /$ day. Its monthly CPUE was highest in April at 19,800.28 kg/day and lowest in December at 9,624.83 kg/day. The total catch of the commercial subsector for 2013 was 22,855,452.85 kg with April registering the highest at $4,116,650.9 \mathrm{~kg}$ and lowest in December at 313,980 kg. Overall, Sardinella lemuru constituted $45.89 \%$ of the total commercial sector production for 2013, followed by Amblygaster sirm at 13.19\%, Selar crumenophthalmus at $8.93 \%$, Rastrelliger kanagurta at $8.81 \%$ and Decapterus macrosomaat $8.17 \%$. The most exploited species was Decapterus macrosoma caught by Purse Seine with an E value of 0.71, followed by Sardinella lemuru with 0.59, Amblygaster sirm with 0.57, and Rastrelliger kanagurta with 0.51. The species Selar crumenophthalmus has the lowest $\mathrm{E}$ value at 0.38 . The maximum length (Lmax) of S. lemuru, A. sirm, R. kanagurta, and D. macrosoma are much higher than the published values of length at first maturity of subject species. Decapterus macrosoma, S. lemuru, A. sirm, and R. kanagurta all have higher fishing mortality than natural mortality suggestive of overexploitation. Amblygaster sirm and Rastrelliger kanagurta caught by purse seine were both captured before maturity with L25 values of $15.0 \mathrm{cms}$ and $19.0 \mathrm{~cm}$ respectively while Sardinella lemuru and Decapterus macrosoma were already matured when captured with values of $15.0 \mathrm{~cm}$ and $19.0 \mathrm{~cm}$, respectively. Fishing pressure on the most dominant species, S. lemuru, is high and its maximum length has gone down by as much as $23 \%$ over the past decade.

${ }^{\star}$ E-mail: rcalangit28@gmail.com

Keywords: maximum length, fishing mortality

Received: 24 February 2017

Accepted: 12 June 2017 Sulu Sea, Basilan Strait purse seine

\section{I N T ROD UCT I O N}

I $\mathrm{n}$ the Philippines, the small pelagic fish as a group consists predominantly of round scads (Decapterus spp.), anchovies (Stolephorous spp.), sardines (Sardinella spp.,), and mackerels (Rastrelliger spp.). Included in this group are the herrings (Clupeidae), fusiliers (Caesionidae), bigeyed scads (Carangidae), flying fishes (Exocoetidae), and halfbeaks (Hemiramphidae). Small pelagic fishes are usually found in continental shelf waters (not exceeding $200 \mathrm{~m}$ depth). They generally attain maximum weights not exceeding $500 \mathrm{~g}$ and have fast growth rates and short life spans (Zaragoza et. al. 2004).

In 2001, the country's small pelagic fisheries subsector production was about 1.1 million MT or roughly $35 \%$ of the total fisheries production. It is considered the main source of inexpensive animal protein for lower income groups in the Philippines. These groups constitute about $70 \%$ of the population and spend over
$65 \%$ of their income on food. Thus, fisheries management is very important for the county's food security (Zaragoza et. al. 2004)

Capture fisheries in many parts of the Philippine archipelago is an important activity and this is also the case in the Zamboanga peninsula. Finfish species in this area are being caught using a variety of fishing gears such as purse seines, trawls, and other efficient fishing methods that can massively harvest these wild stocks (Stergiou et al. 1997).

In Zamboanga Peninsula (Region IX), 76.21\% of all small commercial, $97 \%$ of all medium scale commercial, and $100 \%$ of all large commercial fishing vessels are based in Zamboanga City. In terms of gross tonnage, Zamboanga City constitutes $98.1 \%$ of all commercial fishing capacity (BFAR IX 2014). The most prevalent fishing gear used by the commercial fishing sub-sector is the purse seine which constitutes $31.2 \%$ (NSAP 2013). 
In the early 1990s, a decline has been observed in the municipal fisheries but was offset by commercial fisheries. Around $47 \%$ of capture fisheries production ( 787,000 tons) came from municipal fisheries and the rest ( $\sim 885,000$ tons) from commercial fisheries (Barut et al. 1997).

In spite of its vast and rich fishing areas and its substantially large share in the country's national capture fisheries production, very few published studies are available regarding its status. Available reports dealing with stock assessment and its fishery status were done a few years ago such as those of Dalzell and Ganaden (1987) and Sajili et al. (2003, unpublished). Evidently, much is not known about the biology and status of the fishery stocks. The need to manage the exploitation of the fishery resources was already recognized as early as the 1960s and repeatedly echoed for several decades (Armada 2004). This study was undertaken to assess the status of the fishery stocks to serve as a basis for imposing catch ceiling limitations and the establishment of a closed season in the area (in accordance with Republic Act 8550, Chapter II, Sections 8 and 9). This will also aid in promoting the proper utilization, management, and conservation of fishery and other aquatic resources, including the crafting of relevant policies.

\section{MATERIALS AND METHODS}

\section{Study Site}

The study was conducted around the west coast of Zamboanga City. This includes the common landing sites in two (2) localities in the area of Brgy. Baliwasan (Petron and Tres Marias) and two (2) sites in Brgy. Cawit (Universal and A.M.R).

\section{Data Collection}

Data collection for the study was conducted in the landing sites of Zamboanga City for a period of one year (2013 only). There were two trained NSAP enumerators for each landing site. Interviews of key informants (fishers, dealers/buyers, or boat captain) were conducted including information on fishing grounds, types of gear used, total number of boats landed per day, number of fishing days, and total catch per fishing operation. These were recorded on the prepared catch forms. Sampling was done during peak hours of arrival per landing site. Data on CPUE, species composition, and length frequency of fish landed were computed/obtained using entries in the NSAP Form 2b. Apart from boats sampled, landed catch of fishing boats that were not sampled were also taken to obtain the total catch for a particular day.

For length-frequency data sampling, at least $1 \mathrm{~kg}$ of samples from each batch of catch was randomly selected and sorted out according to fish species (NSAP methodology by Lopez, undated). Samples were weighed first (in $\mathrm{kg}$ ), then total length (in $\mathrm{cm}$ ) taken using a ruler. Monthly data were summarized and tabulated by species composition and gear type.
Catch per unit effort (CPUE), a standard unit of effort in kilograms per day ( $\mathrm{kg} /$ day) formulated by BFAR according to the type of fishing gear, was used to determine monthly CPUE. It is computed by taking the quotient of the catch (in $\mathrm{kg}$ ) over the average fishing days. CPUE of the dominant fishing gear (purse seine) in the monitored sites was computed using actual and raised data. The CPUE of the top five fishing gears were plotted for comparison purposes only with that of the purse seine to justify the focus on the subject gear.

the total fish catch was determined through interviews and actual ocular verification of catch by the enumerators of the boats sampled. The catch of the boats that were not sampled was obtained through interviews and added to the figure of the boats that were sampled to arrive at the total catch for the day.

\section{Dominant Species}

The dominant species was determined by identifying the species with the biggest volume, followed by the next highest, and so on.

\section{Population Parameters}

Population parameters presented were obtained using the FAO-ICLARM Stock Assessment Tools (FISAT) software (Gayanilo et al. 1996). The software includes the Electronic Length Frequency Analysis (ELEFAN) routines to estimate the parameters of the von Bertalanffy Growth Function (VBGF). The asymptotic length $\left(\mathrm{L}_{\infty}\right)$ and the growth constant $(\mathrm{K})$ value were estimated via $\mathrm{K}$-scan routine of ELEFAN 1, wherein the $\mathrm{K}$-value is chosen to provide the "best fit" for the available length-frequency data of a particular species. The ratios of the coefficients of mortality and growth $(\mathrm{Z} / \mathrm{K})$ were estimated using the Powell-Wetherall plot (Powell 1979; Wetherall 1986). Natural mortality (M) was estimated using the M-empirical equation of Pauly (1984). Values obtained for mortality were used for the computation of exploitation rate (E). Probabilities of capture for the selected species were estimated from the left ascending arm of the catch curves. This involves extrapolating the right descending side of the catch curve such that fish that "ought" to have been caught are added to the curve, with the ratio of "expected" numbers to those that are actually caught being used to estimate the probabilities of capture.

Growth parameters were determined first by estimating $\mathrm{L}_{\infty}$ (asymptotic length) using the PowellWetherall method (Gayanilo and Pauly 1997) based on the equation of Beverton and Holt (1956):

$$
\mathrm{Z}=\mathrm{k}\left(\left(\mathrm{L}_{\infty}-\mathrm{L}\right) /\left(\mathrm{L}-\mathrm{L}^{\prime}\right)\right)
$$

where $\mathrm{Z}$ is the total instantaneous mortality, $\mathrm{k}$ is the growth coefficient, $\mathrm{L}$ is the mean length, $\mathrm{L}_{\infty}$ is the asymptotic length, and L' is the initial length of the sample.

The estimated values of $\mathrm{L}_{\infty}$ were further processed in ELEFAN I (ELectronicLEngth Frequency ANalysis) 
Table 1. Number and distribution of commercial fishing boats (Source: BFAR-IX, 2014)

\begin{tabular}{lccccc}
\hline \multicolumn{1}{c}{ Area } & Small scale & Medium scale & Large scale & Undetermined & Total \\
\hline Zamboanga City & 157 & 449 & 95 & 7 & 708 \\
Zambo.Del Norte & 9 & 4 & 0 & - & 13 \\
Zambo.Del Sur & 24 & 2 & 0 & - & 26 \\
Zambo. Sibugay & 15 & 4 & 0 & - & 19 \\
Isabela City & 1 & 4 & 0 & - & 5 \\
\hline Total & 206 & 463 & 95 & 7 & 771 \\
\hline
\end{tabular}

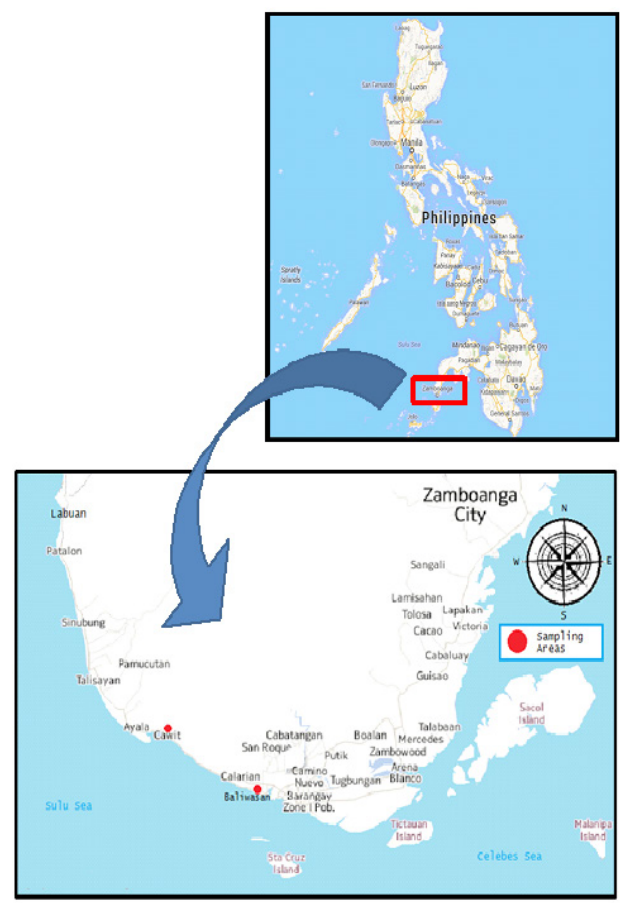

Figure 1. Zamboanga City map showing landing sites.

for the verification of the value for Loo and $\mathrm{k}$. Analysis in the estimation of growth parameters and mortality uses the von Bertalanffy (1934) growth equation:

$$
\mathrm{Lt}=\mathrm{L}_{\infty}(1-\mathrm{e}-\mathrm{k}(\mathrm{t}-\mathrm{to}))
$$

Where Lt is the length of fish at age $t$, e is the Naperian logarithm, and to be the hypothetical age the fish would attain at length zero.

Mortalities and exploitation rate were then calculated using the equation:

$$
\mathrm{Z}=\mathrm{M}+\mathrm{F}
$$

where $\mathrm{Z}$ is the instantaneous total mortality, $\mathrm{M}$ is the instantaneous natural mortality due to predation, aging, and other environmental causes, and $\mathrm{F}$ is the instantaneous fishing mortality caused by fishing.

Furthermore, $M$ was estimated using the empirical formula of Pauly (1984):

$$
\log M=0.654 \log k-0.28 \log L_{\infty}+0.463 \log T
$$

Where $\mathrm{L}_{\infty}$ and $\mathrm{k}$ are the VBGF growth parameters. and $\mathrm{T}$ is the annual mean habitat temperature $\left({ }^{\circ} \mathrm{C}\right)$ of the water in which the stock in question lives.

Expanding the equation for mortality would lead to the computation of exploitation rate using:

$$
\mathrm{E}=\mathrm{F} / \mathrm{Z}
$$

Where $\mathrm{E}$ is the exploitation rate. The use of equations from growth parameters and mortalities, prediction of recruitment patterns, and virtual population analysis could be estimated using the routines found in FISAT programs.

\section{RESULTS AND DISCUSSION}

The commercial fisheries subsector in the Zamboanga Peninsula is unique in that $76 \%$ of smallscale, $97 \%$ of medium-scale, and $100 \%$ of large-scale commercial fishing vessels are based in Zamboanga City alone, and only $24 \%$ of small-scale and $3 \%$ of mediumscale are based in the other localities of the three provinces of Zamboanga Del Sur, Zamboanga Del Norte, and Zamboanga Sibugay. In terms of the number of units, Zamboanga City is home to $31 \%$ of all commercial fishing boats, but in terms of boat tonnage, the city hosts the lion's share with $98.1 \%$ of total gross tonnage.

\section{Monitored Fishing Boats}

Figure 2 shows that the majority of the fishing boats that operated in the area used the gear purse seine, with total boat units of 248 or $75.4 \%$ of the overall monitored commercial fishing boats in the Zamboanga Peninsula. It was followed by bag net and ring net with identical 29 units each (NSAP 2014).

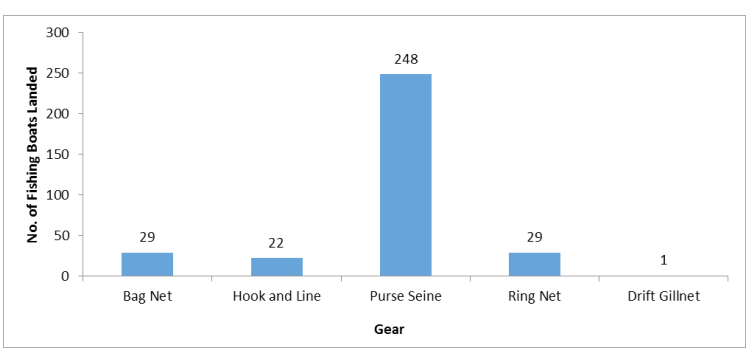

Figure 2. Number of monitored commercial fishing boats in Zamboanga Peninsula 


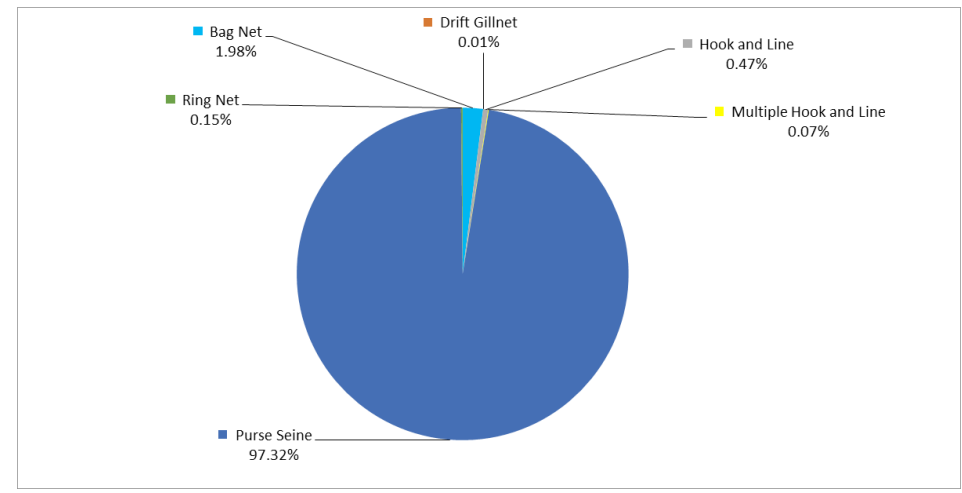

Figure 3. Share of catch of dominant commercial fishing gears

Figure 3 contributes to the uniqueness of the commercial fisheries situation in the Zamboanga Peninsula as it is almost exclusively the domain of purse seine in terms of catch.

Catch records show that purse seine has the highest catch volume with 22,243.86 MT or $97.32 \%$ of total annual catch, followed by bag net with $452.15 \mathrm{MT}$ or $1.98 \%$, while the lowest volume was registered by the gear multiple hook and line with 15.98 MT or only $0.07 \%$ of the total landed catch in the area.

\section{Dominant Species}

The species Sardinella lemuru dominated fish production in 2013 (Figure 4). Sardines (S. lemuru, A. sirm, and S. gibbossa) made up $60.6 \%$ of total commercial fisheries production in. The top ten (10) species constituted $94.8 \%$ of the total catch which was mostly pelagic fish species. The next most dominant was Amblygaster sirm, also a sardine species, at $13.2 \%$, followed by Selar crumenophthalmus at $8.9 \%$, Rastrelliger kanagurta at $8.8 \%$, Decapterus macrosoma at $8.2 \%$, Decapterus russelli at $2.9 \%$, Rastrelliger brachysoma at $2.5 \%$, Decapterus tabl at 2.2\%, Sardinella gibbosa at $1.5 \%$ and the last at the tenth place is the species Auxis rochei at $0.8 \%$ comprised catch.

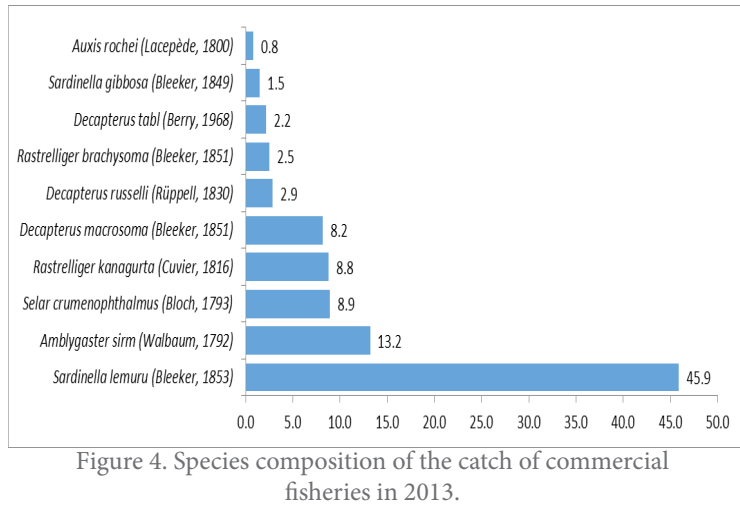

\section{Landed Catch}

The total landed catch for this study period (2013) yielded 22,937.40 MT. Catch figures show that commercial fishing recorded the biggest volume with 22,855.50 MT while municipal fishing registered only 81.93 MT. Figure 5 shows that April had the highest landed catch with 4,116.7 MT. This was followed by the months of May and June, while lowest was in December with 314 MT. There was a sudden drop in the volume of catch in September because that was the time when the month-long Zamboanga siege occurred which prevented many fishing boats from going out to fish.

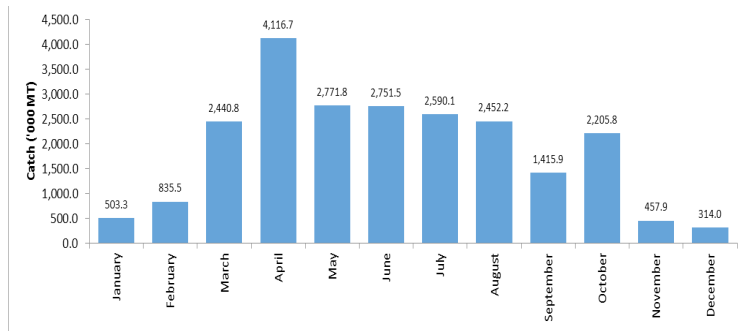

Figure 5. Monthly distribution of landed catch (MT) of the commercial fisheries sector

Since the majority of the catch of the commercial fisheries subsector is made up of sardines, there is some apprehension that the increased effort in April might have an adverse effect on the minor peak of sardine spawning which occurs between April and May (UNDP-GEF SCS SFM Project, unpublished).

\section{Catch per Unit Effort}

Figure 6 shows that April of 2013 had the highest production, followed by the month of May. The months of November to February have the lowest landed catch which coincided with the implementation of the closed season for sardines under the Joint DA-DILG Administrative Order No.1. Catch per unit effort is also highest during the month of April, while the month of December has the lowest catch volume It is notable that the high CPUE in April was somewhat sustained through October. The annual average CPUE of the commercial fisheries sector was $10,890.5 \mathrm{~kg} /$ day.

In general, the catch was proportionate with the effort except for the months of September and October when the month-long Zamboanga Siege prevented most of the commercial fishing boats from fishing. 
Table 2. Growth parameter estimates of the dominant pelagic fish species for 2013

\begin{tabular}{|c|c|c|c|c|c|}
\hline \multirow{2}{*}{ Species } & \multirow{2}{*}{ Gear } & \multicolumn{4}{|c|}{ Growth } \\
\hline & & $\mathrm{L} \max$ & $\mathbf{L} \infty$ & $\mathbf{k}$ & $\varnothing$ \\
\hline Sardinella lemuru & Purse Seine & 19.76 & 20.25 & 0.64 & 2.419 \\
\hline Amblygaster sirm & Purse Seine & 23.68 & 24.1 & 0.4 & 2.366 \\
\hline Rastrelliger kanagurta & Purse Seine & 32.73 & 32.9 & 0.22 & 2.377 \\
\hline Selar crumenophthalmus & Purse Seine & 26.48 & 27.1 & 0.34 & 2.397 \\
\hline Decapterus macrosoma & Purse Seine & 22.09 & 22.1 & 0.37 & 2.257 \\
\hline
\end{tabular}

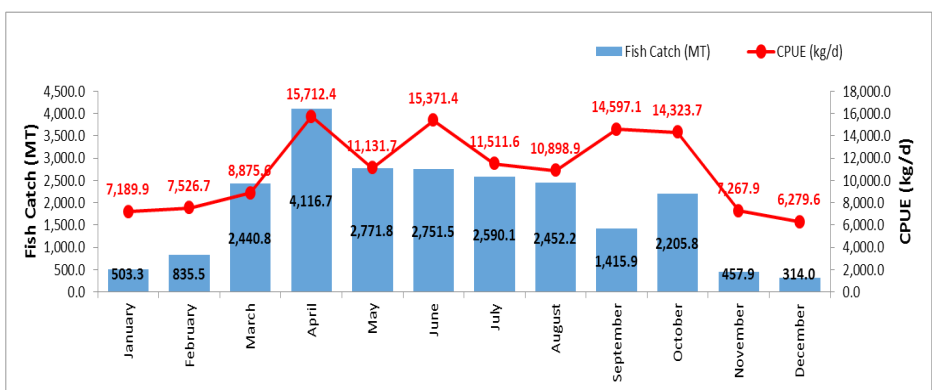

Figure 6. Monthly fish harvest and CPUE trend of commercial fisheries

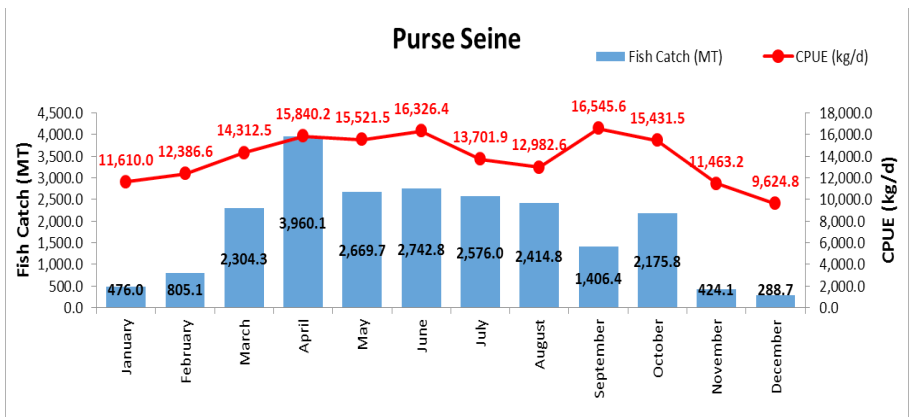

Figure 7. Monthly harvest and CPUE of the Gear Purse Seine.

The monthly CPUE trend of the dominant gear, purse seine, likewise mirrors those of the commercial fisheries subsector but with a much higher annual average of $14,142 \mathrm{~kg} /$ day where the peak was in April with a CPUE of 19,800 kg/day (Figure 7). This average CPUE is much higher than the CPUE for purse seine in Western and Central Visayas in 2002 with a value of $8,933.24 \mathrm{~kg} /$ day as reported by Guanco et.al (2002).

\section{Biological Parameters Estimates}

Growth, mortality, and probability of capture parameters values were obtained using FAO-ICLARM Stock Assessment Tools (FISAT) software (Gayanilo et al. 1996).

\section{Growth}

Table 2 reveals that the five dominant species caught by purse seine have maximum length $\left(\mathrm{L}_{\max }\right)$ values that are very near (less than 1 unit) the asymptotic length $\left(\mathrm{L}_{\infty}\right)$ values, suggesting that the commercial fisheries subsector in the Zamboanga Peninsula is obtaining relatively the maximum possible yield from the subject fishery (Froese and Pauly 2000).
The maximum length $\left(\mathrm{L}_{\max }\right)$ of $S$. lemuru, $A$. sirm, R. kanagurta, and D. macrosoma are much higher than the published values of length at first maturity of subject species. This implies that said species had the opportunity to reproduce and contribute to recruitment. There is no published value for length at first maturity for S. crumenophthalmus, so no comparison can be made, but if the exploitation rate for the species (Figure 7) is any indication, its maximum length could be higher than its length at first maturity.

The maximum length and asymptotic length of the most dominant species, $S$. lemuru, caught by purse seine in Zamboanga in 2013 are significantly lower by $23 \%$ and $22 \%$ respectively than those of the same species caught in Western and Central Visayan Sea in 2002 (Guanco 2009). In the light of the findings that S. lemuru in the Philippines belongs to the same stock (Santos et. al), it appears that the Bali sardines caught by purse seine in Zamboanga have become smaller, an indication of overexploitation.

\section{Mortality}

The mortality of a cohort is composed of mortality due to fishing (F), and mortality caused by 
Table 3. Mortality estimates of the dominant pelagic fish species for the year 2013

\begin{tabular}{|c|c|c|c|c|c|}
\hline \multirow{2}{*}{ Species } & \multirow{2}{*}{ Gear } & \multicolumn{4}{|c|}{ Mortality } \\
\hline & & $\mathbf{F}$ & $\mathrm{M}$ (at $280 \mathrm{C})$ & $\mathrm{E}$ & $\mathrm{Z}$ \\
\hline Sardinella lemuru & Purse Seine & 2.18 & 1.49 & 0.59 & 3.67 \\
\hline Amblygaster sirm & Purse Seine & 1.37 & 1.04 & 0.57 & 2.41 \\
\hline Rastrelliger kanagurta & Purse Seine & 0.66 & 0.65 & 0.51 & 1.31 \\
\hline Selar crumenophthalmus & Purse Seine & 0.55 & 0.91 & 0.38 & 1.46 \\
\hline Decapterus macrosoma & Purse Seine & 2.52 & 1.02 & 0.71 & 3.53 \\
\hline
\end{tabular}

Table 4. Probability of capture estimates of the dominant pelagic fish species for 2013

\begin{tabular}{cccc}
\hline \multirow{2}{*}{ Species } & \multirow{2}{*}{ Gear } & \multicolumn{2}{c}{ Probability of Capture } \\
\cline { 3 - 4 } & & L25 & L50 \\
\hline Sardinella lemuru & Purse Seine & 15.05 & 15.67 \\
Amblygaster sirm & Purse Seine & 14.68 & 15.33 \\
Rastrelliger kanagurta & Purse Seine & 13.01 & 13.45 \\
Selar crumenophthalmus & Purse Seine & 17.91 & 19.18 \\
Decapterus macrosoma & Purse seine & 19.04 & 19.97 \\
\hline
\end{tabular}

predation, disease, and deaths due to aging, which is known as natural mortality (M). With these factors, exploitation rate (E) can be computed using the ratio of fishing mortality (F) over total mortality (Z), and the resulting value will indicate the fishing condition of a certain area.

Pauly and Ingles (1984) stated that the optimum fishing mortality in an exploited stock should be approximately equal to natural mortality, or optimum exploitation rate is approximately equal to 0.50 . A predominance of estimates of values of $\mathrm{E}>0.5$ in a number of stocks should be suggestive of overexploitation.

In the table of the five dominant species (Table 3), D. macrosoma, S. lemuru, A. sirm, and R. kanagurta all have higher fishing mortality than natural mortality suggestive of overexploitation.

The higher rate of fishing mortality than natural mortality indicated in Table 3 further confirms the notion of overexploitation of the sardine stocks.

The exploitation rates for the dominant species are all above the threshold except for Selar crumenophthalmus which is unusually low (Figure 8). Selar crumenophthalmus is the only species that show apparently no sign of overfishing since natural mortality is higher than the fishing mortality. This is understandable because purse seine catches only the big-eyed scad occupying the upper layer of the water column while the bigger ones apparently residing in the deeper portions as shown by the assessment study of Honda Bay (Ramos et al, undated) are beyond the reach of the purse seine nets. This situation can lead to improved recruitment by giving the species the opportunity to reproduce.

\section{Probability of Capture}

In Table 4, Amblygaster sirm and Rastrelliger kanagurta caught by purse seine were both captured before maturity and could have dire consequences for the fish populations. The figures for Sardinella lemuru

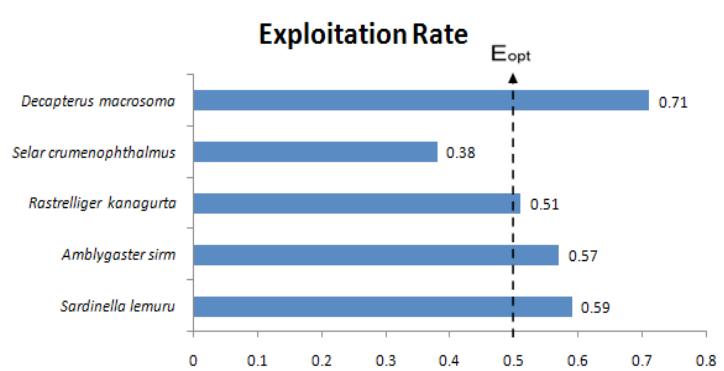

Figure 8. Exploitation rates of dominant pelagic fish species caught by purse seine

and Decapterus macrosoma indicate that these were already matured when captured and may have had the opportunity to spawn and contribute to recruitment.

\section{S UMMAR Y}

The Zamboanga Peninsula is the major source of the country's sardine production where the major gear used is the purse seine which contributed almost to the entire commercial fisheries production (97\%). In terms of capacity, more than $98 \%$ of the total gross tonnage of commercial fishing is based in Zamboanga City. Sardines dominate the fish catch, making up $60 \%$ of the total fish catch.

The catch per unit effort of the whole commercial fisheries subsector for 2013 averaged $10,890.5 \mathrm{~kg} /$ day while that of the dominant gear, purse seine, was higher at $14,142 \mathrm{~kg} /$ day. Generally, the catch per unit efforts of both the commercial fishing subsector and that of purse seine alone are directly proportionate to the volume of catch landed.

The maximum length and the asymptotic length of S. lemuru, the most dominant species caught by the purse seine in 2013 was smaller than that of the same species caught in the Visayas which indicates that the sardines are getting smaller. This situation warrants 
further studies on their biology and economics to further enhance the management measures for the species already in place.

\section{R E F E R E N C E S}

Armada, NB. 2004. State of demersal fisheries. In: Department of Agriculture-Bureau of Fisheries and Aquatic Resources (DA-BFAR), In Turbulent Seas: The Status of Philippine Marine Fisheries, p. 42-46. Coastal Resource Management Project (CRMP), Cebu City, Philippines.

Barut NC, Santos MD, Garces LR. 2004. Overview of the Philippine marine fisheries. In: DA-BFAR, In Turbulent Seas: The Status of Philippine Marine Fisheries, p. 22-31. CRMP, Cebu City, Philippines.

Beverton RJH, Holt SJ. 1956. A review of methods for estimating mortality rates in exploited fish populations with special reference to sources of bias in catch sampling. Rapp. P.v. Reun. CIEM 140: 6783.

Dalzell P, Ganaden R. 1987. A review of the fisheries for small pelagic fishes in the Philippine waters. BFAR Tech. Paper Ser. 10(1): 54.

FAO (Food and Agriculture Organization of the United Nations). 1998. Yearbook of Fisheries Statistics. FAO, Rome, Italy.

Froese R, Pauly D, editors. 2000. Fish Base 2000: concept, design, and data sources. ICLARM, Los Banos, Laguna, Philippines. p. 344.

Gayanilo FC Jr, Pauly D. 1997. FAO-ICLARM Stock Assessment Tools, Reference Manual. FAO and International Center for Living Aquatic Resources
Management (ICLARM), Rome. p. 219.

Gayanilo FC Jr, Sparre P, Pauly D. 1996. FAO-ICLARM Stock Assessment Tools (FISAT): User's Manual. FAO Computerized Information Series (Fisheries) No. 8. Rome, FAO. p. 126.

Guanco MR, Mesa SV, Belga PB, Nunal DRM. 2002. Assessment of the Commercial Fisheries of Western and Central Visayan Sea. National Stock Assessment Project. Bureau of Fisheries and Aquatic Resources. Regional Field Office 6 and 7. Iloilo and Cebu City, Philippines.

Pauly D. 1984. Length converted catch curves: a powerful tool for fisheries research in the tropics (part II). ICLARM Contribution No. 173. ICLARM, Metro Manila, Philippines, p. 74-76.

Pauly D, Ingles J. 1984. Atlas of the Growth, Mortality and Recruitment of the Philippine Fishes. Institute of Fisheries Development and Research, College of Fisheries, University of the Philippines, Diliman, Quezon City, and ICLARM, Metro Manila, Philippines.

Stergiou KI. 2002. Overfishing, tropicalization of fish stocks, uncertainty and ecosystem management: resharpening Ockham's razor. Fish Res 55:1

Von Bertalanffy L. 1934. Untersuchungen uber die Gesetzlichkeiten des Wachstums 1. Allgemeine Grundlagen derTheorie. Roux' Arch. Entwicklungsmech. Org. 131: 613-653.

Zaragosa EC, Pagdilao CR, Moreno EP. 2004. Overview of the small pelagic fisheries. In: DA-BFAR, 2004. pp. 32-37. 